\title{
Calibration of Soil Test, Fertilizer Dose and Crop Yield with and without FYM for Hybrid Rice (Var.Irh-103) under Sri In Vertisol of Chhattisgarh Plain
}

\author{
Anurag Gupta*, Rakesh Banwari, L. K. Srivastava and G. K. Jatav \\ Indira Gandhi Krishi Vishwavidyalaya, Raipur (Chhattisgarh), India \\ *Corresponding author
}

Keywords

farm of IGKV, soil test, crop yield organic source (FYM)

Article Info

Accepted:

28 February 2020

Available Online:

10 March 2020

\section{A B S T R A C T}

Field experiment was conducted during kharif season of 2018 at the instructional farm of IGKV, Raipur to calibrate soil test, fertilizer dose and crop yield for hybrid rice under SRI method. Various basic parameters viz. nutrient requirement, Contribution of nutrients from soil, fertilizer and organic manure (FYM) were obtained. It was found that hybrid rice (var. IRH-103) required $1.57 \mathrm{~kg} \mathrm{~N}, 0.32 \mathrm{~kg} \mathrm{P}$ and $1.71 \mathrm{~kg} \mathrm{~K}$ to produce one quintal grain yield. The efficiencies of fertilizer and soil test in terms of available nutrients were estimated as 32.66, 73.38, 16.39 percent and 39.87, $30.53,94.53$ percent respectively for $\mathrm{N}, \mathrm{P}$ and $\mathrm{K}$. The efficiency of FYM was evaluated as 13.01, 5.43 and 10.10 percent for N, P and K respectively. Fertilizer adjustment equations were evolved for SRI rice crop to achieve a definite yield target based on the basic parameters viz. nutrient requirement, efficiencies of fertilizer, soil test and organic source (FYM). The ready reckoners for rice with the use of 5 tones of FYM were prepared for various yield targets by using the equation.

\section{Introduction}

Rice is the major food grain crop of Indian economy. India is the world's 2nd largest producer with approximately $43.2 \mathrm{~m}$. ha planted area. In the year 2016-17 the production of rice in the country was 110.15 M.T. with an average productivity of 25.5 q/ha (Pocket book of Agricultural statistics, 2017). In Chhattisgarh, rice crop occupies
4.05 million ha area and produce 8.79 million tons yield (2016-17). The productivity of rice in the state was $2.17 \mathrm{t} / \mathrm{ha}$ (Agricultural statistics, 2017) which is quite low in comparison of the national average.

Area under hybrid rice is continuously increasing. Area under hybrid rice was 10,000 hectare in 1995 which drastically changed to 1 million hectare in 2006. Area under hybrid 
rice was over 2.5 million hectares during 2014, which was about $5.6 \%$ of the total rice cultivated area in the country. (Vadlamani, 2016). System of Rice Intensification (SRI) method of rice production was developed in Madagascar in early eighties. This method showed that the yield of the rice crop can be significantly increased by growing the rice plants in a reduced plant density generally in $25 \times 25 \mathrm{~cm}$. This method includes cultivation of rice with higher amount of organic matter. The younger seedlings are planted singly with wider spacing in a square pattern and with the amount of irrigation which keeps the soil moist but not inundated and frequent weeding which keeps the soil aerated. The seed rate in SRI method is $2 \mathrm{~kg}$ per acre as compared to $10 \mathrm{~kg}$ per hectare in conventional method.

Considering the high cost of fertilizers and adverse effect of its over use on environmental and soil health, proper organic manure- fertilizer recommendations on the bases of soil test values, residual effect and yield targets becomes vital. At such point of time, unique "inductive cum targeted yield model" of Ramamoorthy et al., (1967) to develop proper manure- fertilizer prescription became very useful (Santhi et al., 2010).

Theory for formulation of optimum fertilizer recommendation for any targeted yield was first given by Troug (1960) which was further modified by Ramamoorthy et al., (1967) as "inductive cum targeted yield model". "Soil test crop response (STCR) studies help to generate fertilizer adjustment equations and calibration charts for recommending fertilizers on the basis of soil tests and achieving targeted yield of crops" (Singh and Biswas, 2000).

\section{Materials and Methods}

A field experiment was conducted at the farm of Indira Gandhi Krishi Vishwavidyalaya,
Raipur (Chhattisgarh) on soil test crop response correlation with SRI hybrid rice (variety IRH-103) during kharif season of 2018 in Vertisol. The soil of the experimental field comes under the soil order of Vertisol. This soil is locally known as Kanhar and identified as Arang II series. It is clayey in texture with $24 \%$ Sand, $23 \%$ silt and $53 \%$ clay, dark brown to black in color, neutral to alkaline in reaction due to presence of lime concretion in lower horizon. The soil is deep to 1-1.5 meter. The structure varied from coarse angular blocky to massive and cloddy and in few cases from prismatic or columnar.

Soil is represented as typical fine montmorillonitic, hyperthermic, udic chromustert. Some physico-chemical properties of experimental soil were analyzed which found $7.7 \mathrm{pH}$ (1:2.5), 0.2 EC (dSm-1), 36.11 CEC (c mol(p+) kg-1), 5.6 Organic C (g kg-1), 221Available $\mathrm{N}$ (kg ha-1), 19.3 Available P (kg ha-1)and 496 Available K (kha-1).The experiment was conducted according to approved layout plan of All India Coordinated Research project for Investigation on Soil Test Crop Response Correlation (STCR). A special field technique developed by Ramamurthy et al., (1967) was used for this study.

The field is splitted in three equal sized vertical strips and is represented as $\mathrm{L}_{0}$ (low fertility strip), $\mathrm{L}_{1}$ (medium fertility strip) and $\mathrm{L}_{2}$ (high fertility strip). Before experiment the graded doses of $\mathrm{N}, \mathrm{P}$ and $\mathrm{K}$ fertilizers are given in the field for creating an fertility gradient and for getting the needed variation in soil fertility in different strips. By applying 0-0-0, 100-75-50 and 200-150-100, $\mathrm{kg} \mathrm{ha}^{-1}$ of $\mathrm{N}, \mathrm{P}_{2} \mathrm{O} 5$ and $\mathrm{K}_{2} \mathrm{O}$ in $\mathrm{L}_{0}, \mathrm{~L}_{1}$ and $\mathrm{L}_{2}$ the soil fertility variation is created according to $\mathrm{N}, \mathrm{P}$ and $\mathrm{K}$ levels in strip. Different sources of N, P and $\mathrm{K}$ such as urea, DAP, and muriate of potash were used. In fertility strips ranges of 
soil fertility were created which were evaluated in terms of variations in yields and soil test values. After creating three equal long fertility strips, each strip (or replication) were further divided into three equal parts for three levels of FYM $\left(0,5\right.$ and $\left.10 \mathrm{t} \mathrm{ha}^{-1}\right)$ and was regarded as block. So that there was each strip have three blocks. The three strips on each level of FYM were the three blocks and hence total 9 blocks has been there in the experimental field. Each block was further divided into 08 equal plots. There were total 72 plots in the experiment.

Total 24 treatment combinations of various of doses of $\mathrm{N}, \mathrm{P}$ and $\mathrm{K}$ fertilizers (21 combinations +03 control) were selected for the application in each fertility strip. The 24 selected fertilizer treatments constituted 4 levels of each of $\mathrm{N}(0,60,120$ and $180 \mathrm{~kg}$ ha1), $\mathrm{P} 2 \mathrm{O} 5$ (0, 40, 80 and $120 \mathrm{~kg}$ ha-1) and $\mathrm{K} 2 \mathrm{O}(0,40,80$ and 120 kgha- 1$)$. These were distributed in each block of the strips having 8 treatments in each block. All three blocks in each strip were introduced in a re-inforced ressolvable block design.

Full dose of P2O5 and $\mathrm{K} 2 \mathrm{O}$ and $1 / 3$ rd of $\mathrm{N}$ were applied as basal, remaining 2/3rd of $\mathrm{N}$ applied in two equal splits as top dressing at tillering and panicle initiation stages. Grain and straw samples were analyzed for N, P and K content (Piper, 1966) and total nutrient uptake was computed using grain and straw yield data.

Using the data on grain yield, nutrient uptake, pre-sowing soil available nutrients and fertilizer doses applied the basic parameter, viz. nutrient requirement ( $\mathrm{kg}$ q-1), contribution of nutrients from soil and fertilizer sources were calculated as described by Ramamoorthy et al., (1967). The contribution of nutrients from applied FYM was estimated by relating the yield with fertilizer nutrients and FYM. These parameters were used for the formulation of fertilizer adjustment equations for deriving fertilizer doses and the soil test based fertilizer prescription in the form of ready reckoners for desired yield target of rice under $\mathrm{N}, \mathrm{P}, \mathrm{K}$ alone as well as IPNS.

\section{Results and Discussion}

\section{Soil test levels by creation of fertility gradient}

Soil fertility variations were intentionally created according to the methodology proposed by Ramamoorthy (1967) by including graded fertilizer doses (Table 1). During the summer season, 2018 maize was planted as exhaust crop for normal transformation of added nutrients into the soil complex. The fodder maize yield in different fertility strips showed that the fertility level gradient exists. Soil was analyzed from each fertility strip after harvesting of maize crop.

Yield of Maize and soil test information (Table 1) demonstrated that soil test value variations of $\mathrm{N}$ (Alkaline $\mathrm{KMnO}_{4}-\mathrm{N}$ ) was little, with respect to $\mathrm{N}$ no gradient was created due to the dynamic nature of $\mathrm{N}$ in the soil furthermore, its various forms are lost through the processes "leaching, volatilization and nitrification".

The fertility gradient was quite significant with respect to $\mathrm{P}$ due to the immobile nature of $P$. It gets fixed in the soil where particularly phosphorus is high in vertisols. Phosphorus ions reacts very rapidly with soil constituents for formation of compounds which are insoluble relying upon the nature of soils nature and subsequently stays in soil. Similar levels of soil test potassium was seen in all strips due to higher $K$ status of the experimental fields soil and conservation of its dynamic harmony. 


\section{Soil nutrient status}

The mean values of available $\mathrm{N}$ of the experimental plots varied from 202.72 to 220 $\mathrm{kg} \mathrm{ha}{ }^{-1}$. Available $\mathrm{P}$ level recorded in the range of 14.77 to $25.68 \mathrm{~kg}$ ha ${ }^{1}$.Correspondingly the mean value of available $\mathrm{K}$ varied from 475.82 to $500.37 \mathrm{~kg} \mathrm{ha}^{-1}$ (Table 2).

The available $\mathrm{N}, \mathrm{P}$ and $\mathrm{K}$ values showed variation among fertility strips however the variation in available $\mathrm{N}$ and $\mathrm{K}$ levels with change in fertility strips were marginal whereas the variation in available $\mathrm{P}$ level in different strips were quite significant (Table 2) and it showed an increase as per fertility strips from $\mathrm{L}_{0}$ to $\mathrm{L}_{2}$. The immobile nature of $\mathrm{P}$ and fixation with soil constituents for formation of compounds of insoluble nature depends on the nature of soil thus it remains in soil. The results showed formation of fertility gradient with respect to available $P$.

The level of available $\mathrm{N}$ and $\mathrm{K}$ do not form this type of gradient since the nature of $\mathrm{N}$ is very mobile and it declines in soil due to the processes like "runoff, leaching, volatilization and de-nitrification". The soil test value of available $\mathrm{K}$ of experimental soil was found to be in high level and maintenance of its dynamic equilibrium may have resulted in less variation on soil test potassium levels in all strips.

\section{Response of rice crop to added nutrients}

The range and mean yield of hybrid rice (IRH-103) presented in table 3 with regarding to three fertility strips. The results showed from $L_{0}$ to $L_{2}$ strip an increasing trend in grain yield. The grain yield of rice increased with respect to fertility gradient it might be due to the fertility gradient created for available $\mathrm{P}$ in soil status from $\mathrm{L}_{0}$ to $\mathrm{L}_{2}$. The response of SRI rice (In terms of grain yield $\mathrm{q} \mathrm{ha}^{-1}$ ) to fertilizer
$\mathrm{N}, \mathrm{P}, \mathrm{K}$ and FYM has been showed in graph 1 to 4 . Rice crop responses to the $\mathrm{N}$ and $\mathrm{P}$ fertilizer was good whereas the response to $\mathrm{K}$ fertilizer was comparatively less consistent. FYM application response it the form of nutrients source was not quite marked by the crop as shown in graph (Fig.4). "Mahindar Kumar et al., (2009), Pandey et al., (2009), Singh et al., (2009) and Banerjee and Pal (2009)" already resulted on responses of various crops to applied N, P, K and FYM.

The relations between rice yields and various plant nutrients acting as independent variable were acquired by the use of regression analysis for evaluation of the yield variation due to various nutrients as given in table 4 . The higher variation in grain yield of SRI rice was accounted for $\mathrm{N}$ alone as showed by the results.

Higher crop responses $\left(\mathrm{R}^{2}=0.846\right)$ were assigned to the high $\mathrm{N}$ requirement and due to its mobile nature, it is accessible to the plant in the root system sorption zone (Ramamoorthy et al., 1967). The remaining variation in the yield was caused by fertilizer $\mathrm{P}_{2} \mathrm{O}_{5}$ and $\mathrm{K}_{2} \mathrm{O}$. The insoluble compounds are formed by $\mathrm{P}$ ions by its reaction with soil constituent hence they are immobile in soil. Results revealed that the rice crop showed less requirement of $\mathrm{P}$ nutrient as compared to $\mathrm{N}$.

Rice yield responses curvilinear nature to $\mathrm{P}$ application also did not get reflected on yield variation because of the poor $R^{2}$ value as compared to linear relationship. The yield variation caused due to FYM application was also seen to have very poor correlation. The combination of fertilizer $\mathrm{N}$ and fertilizer $\mathrm{P}$ was highly responsive to the yield as showed by the equation. (Table- 4) In Figure 1 the higher value $\mathrm{R}^{2}$ (regression coefficient) shows higher correlation between yield and nutrient $(\mathrm{N})$. 
Relationship between yield and nutrient uptake

The hybrid rice crop yield showed close interrelation with total uptake of $\mathrm{N}, \mathrm{P}$ and $\mathrm{K}$. Nutrient requirement for rice crop was estimated by using this relation (Table-5). Nutrient requirement can be defined as "the amount of nutrient $(\mathrm{kg})$ required to produce per unit amount of yield. The nutrient requirement can be given by using the regression coefficient (b1) of yield (Y) and total nutrient uptake $(\mathrm{U})$ ".

$$
\mathrm{Y}=\mathrm{b} 1 \mathrm{U} \text { or } \mathrm{U}=1 / \mathrm{b} 1 * \mathrm{Y}
$$

Where, 1/ b1 gives the NR (Nutrient requirement)

Table-5 showed that there is almost close linear relation observed between hybrid rice yield and total nutrient uptake. Relationship between nitrogen uptake and rice yield were found highest nearly one $\left(\mathrm{R}^{2}=0.97\right)$ among the $\mathrm{N}, \mathrm{P}$ and $\mathrm{K}$ uptake.

\section{Efficiencies of fertilizer, soil test and FYM}

The software developed by AICRP on STCR Indian Institute of Soil Science, Bhopal (MP) was used for calculation of contribution of nutrient from fertilizer, soil and FYM in term of percent efficiency of fertilizer, soil test and FYM (results given in the table 6). Efficiencies for $\mathrm{N}, \mathrm{P}$ and $\mathrm{K}$ fertilizers were estimated as 39.87, 30.53 and 94.53 percent respectively. In same way the soil test efficiencies were recorded as 32.66, 73.38 and 16.39 percent NPK, respectively. The organic source (FYM) efficiency was found as $13.01 \%, 5.43 \%$ and $10.10 \%$ for $\mathrm{N}, \mathrm{P}$ and $\mathrm{K}$ respectively.

Due to various processes such as denitrification, volatilization, leaching,, and runoff approximately $2 / 3^{\text {rd }}$ percent of the fertilizer nitrogen applied was lost. A big part of the applied phosphorus gets fixed in the soil by reaction with dominant cations such as $\mathrm{Fe}, \mathrm{Mn}, \mathrm{Ca}, \mathrm{Mg}$ etc present in soil. Efficiency of fertilizer $\mathrm{K}$ applied was recorded to be higher due to its greater uptake by plants as luxury consumption. The soil test efficiency was lower as compared to fertilizer efficiency for $\mathrm{N}$ and $\mathrm{K}$ but it was recorded to be higher for soil test $\mathrm{P}$. Ramamoorthy et al., (1967), Srivastava et al., (2017), Sahu et al., (2017), Regar and singh (2014), Parihar et al., (2015) also calculated efficiencies for soil, fertilizer and FYM respectively.

Table.1 Pre requisite fertilizer doses given in various strips for creating fertility gradient in the field and maize fodder yield during summer season of 2018

\begin{tabular}{|c|c|c|c|c|c|c|c|}
\hline \multirow[t]{2}{*}{$\begin{array}{l}\text { Fertility } \\
\text { strips }\end{array}$} & \multicolumn{3}{|c|}{$\begin{array}{l}\text { Fertilizer doses } \\
\left(\mathbf{k g ~ h a}^{-1}\right)\end{array}$} & \multirow[t]{2}{*}{$\begin{array}{c}\text { Fodder yield of } \\
\text { maize }\end{array}$} & \multicolumn{3}{|c|}{$\begin{array}{l}\text { Post harvest soil test values (kg } \\
\text { ha }^{-1} \text { ) }\end{array}$} \\
\hline & $\mathbf{N}$ & $\mathbf{P}_{2} \mathbf{O}_{5}$ & $\mathbf{K}_{2} \mathbf{O}$ & & SN & $\mathbf{S P}$ & SK \\
\hline $\mathbf{L}_{\mathbf{0}}$ & 0 & 0 & 0 & 19.10 & 226.0 & 11.27 & 469.5 \\
\hline $\mathbf{L}_{1}$ & 100 & 75 & 50 & 21.81 & 233.0 & 17.56 & 483.0 \\
\hline $\mathbf{L}_{2}$ & 200 & 150 & 100 & 26.48 & 238.5 & 26.96 & 488.5 \\
\hline
\end{tabular}


Table.2 Range and mean values of soil nutrient status $\left(\mathrm{kg} \mathrm{ha}^{-1}\right)$ in fertility strips of experiment before sowing of crop

\begin{tabular}{|c|c|c|c|c|c|}
\hline Soil Nutrients & $\mathbf{L}_{\mathbf{0}}$ & $\mathbf{L}_{1}$ & $\mathbf{L}_{2}$ & S.D. & C.V. $(\%)$ \\
\hline $\begin{array}{l}\text { Alkaline } \\
\text { KMnO4-N }\end{array}$ & $\begin{array}{c}176.2-208.8 \\
(202.72)\end{array}$ & $\begin{array}{c}196.6-229.9 \\
(216.6)\end{array}$ & $\begin{array}{c}199.5-229.9 \\
(220)\end{array}$ & 12.43 & 5.83 \\
\hline Olsen's P & $\begin{array}{c}7.88-17.16 \\
(14.77)\end{array}$ & $\begin{array}{c}14.86-29.39 \\
(22.49)\end{array}$ & $\begin{array}{c}21.32-30.28 \\
(25.68)\end{array}$ & 5.87 & 28.00 \\
\hline $\begin{array}{l}\text { Neutral normal } \\
\text { Ammonium } \\
\text { Acetate } \\
\text { extractable K }\end{array}$ & $\begin{array}{c}428.74-476.9 \\
\quad(475.82)\end{array}$ & $\begin{array}{c}464.58-518.34 \\
(488.87)\end{array}$ & $\begin{array}{c}448.90-536.26 \\
(500.37)\end{array}$ & 22.39 & 4.58 \\
\hline
\end{tabular}

Table.3 Range and mean value of grain yields $\left(\mathrm{q} \mathrm{ha}^{-1}\right)$ of rice in relation to fertility strips

\begin{tabular}{|l|c|c|c|}
\hline Crop & $\mathbf{L}_{\mathbf{0}}$ & $\mathbf{L}_{\mathbf{1}}$ & $\mathbf{L}_{\mathbf{2}}$ \\
\hline Rice & $32.00-91.55$ & $37.00-94.00$ & $41.20-93.00$ \\
(IRH-103) & $(68.31)$ & $(72.27)$ & $(75.18)$ \\
\hline S. D. & 18.95 & 19.41 & 17.46 \\
\hline C.V. (\%) & 27.75 & 26.85 & 23.22 \\
\hline
\end{tabular}

Table.4 Selected regression model to account for yield variation of rice

\begin{tabular}{|l|l|l|}
\hline S.No. & Model for SRI rice & $\mathbf{R}^{\mathbf{2}}$ \\
\hline $\mathbf{1 .}$ & $\mathrm{Y}=42.68+0.271 \mathrm{FN}$ & 0.846 \\
\hline $\mathbf{2 .}$ & $\mathrm{Y}=49.05+0.343 \mathrm{FP}$ & 0.537 \\
\hline $\mathbf{3 .}$ & $\mathrm{Y}=56.51+0.249 \mathrm{FK}$ & 0.268 \\
\hline $\mathbf{4 .}$ & $\mathrm{Y}=69.37+0.509 \mathrm{FYM}$ & 0.012 \\
\hline $\mathbf{5 .}$ & $\mathrm{Y}=38.90+0.22 \mathrm{FN}+0.14 \mathrm{FP}$ & 0.905 \\
\hline $\mathbf{6 .}$ & $\mathrm{Y}=40.64+0.25 \mathrm{FN}+0.06 \mathrm{FK}$ & 0.850 \\
\hline $\mathbf{7 .}$ & $\mathrm{Y}=46.90+0.30 \mathrm{FP}+0.08 \mathrm{FK}$ & 0.557 \\
\hline $\mathbf{8 .}$ & $\mathrm{Y}=53.96+0.25 \mathrm{FK}+0.51 \mathrm{FYM}$ & 0.281 \\
\hline $\mathbf{9 .}$ & $\mathrm{Y}=40.14+0.27 \mathrm{FN}+0.51 \mathrm{FYM}$ & 0.859 \\
\hline $\mathbf{1 0}$ & $\mathrm{Y}=46.50+0.34 \mathrm{FP}+0.51 \mathrm{FYM}$ & 0.550 \\
\hline $\mathbf{1 1}$ & $\mathrm{Y}=38.59+0.22 \mathrm{FN}+0.13 \mathrm{FP}+0.015 \mathrm{FK}$ & 0.906 \\
\hline $\mathbf{1 2 .}$ & $\mathrm{Y}=36.04+0.22 \mathrm{FN}+0.13 \mathrm{FP}+0.014 \mathrm{FK}+0.51 \mathrm{FYM}$ & 0.918 \\
\hline $\mathbf{1 3}$. & $\mathrm{Y}=35.47+0.76 \mathrm{SP}+0.31 \mathrm{FP}$ & 0.590 \\
\hline $\mathbf{1 4}$. & $\mathrm{Y}=-81.67+0.18 \mathrm{SK}+0.29 \mathrm{FK}$ & 0.360 \\
\hline $\mathbf{1 5}$. & $\mathrm{Y}=-16.87+0.29 \mathrm{SN}+0.26 \mathrm{FN}$ & 0.886 \\
\hline $\mathbf{1 6}$ & $\mathrm{Y}=47.91+0.27 \mathrm{FN}-0.0003 \mathrm{FN}^{2}$ & 0.860 \\
\hline $\mathbf{1 7}$ & $\mathrm{Y}=50.32+0.59 \mathrm{FP}-0.0015 \mathrm{FP}^{2}$ & 0.570 \\
\hline $\mathbf{1 8}$ & $\mathrm{Y}=57.47+0.43 \mathrm{FK}-0.003 \mathrm{FK}^{2}$ & 0.290 \\
\hline $\mathbf{1 9}$ & $\mathrm{Y}=75.93-0.28 \mathrm{FYM}+0.07 \mathrm{FYM}^{2}$ & 0.018 \\
\hline & & \\
\hline
\end{tabular}


Table.5 Relation of rice yield (Y) with total nutrient uptake (U)

\begin{tabular}{|l|c|c|}
\hline Nutrient & \multicolumn{2}{|c|}{ SRI hybrid Rice } \\
\hline & Y= b1 U (NR*Uptake) & $\mathbf{R}^{\mathbf{2}}$ \\
\hline $\mathbf{N}$ & $\mathrm{Y}=1.59 \mathrm{UN}$ & 0.97 \\
$\mathbf{P}$ & $\mathrm{Y}=0.88 \mathrm{UP}$ & 0.90 \\
$\mathbf{K}$ & $\mathrm{Y}=0.91 \mathrm{UK}$ & 0.83 \\
\hline
\end{tabular}

Table.6 Efficiencies (\%) of fertilizer, soil test and FYM and nutrient requirement of SRI hybrid rice var. IRH-103 $\left(\mathrm{kg} \mathrm{ha}^{-1}\right)$

\begin{tabular}{|c|c|c|c|}
\hline \multirow[t]{2}{*}{ Parameters } & \multicolumn{3}{|c|}{ Rice } \\
\hline & $\mathbf{N}$ & $\mathbf{P}$ & $\mathbf{K}$ \\
\hline Soil test Efficiency (\%) E & 32.66 & 73.38 & 16.39 \\
\hline Fertilizer Efficiency (\%) $E_{f}$ & 39.87 & 30.53 & 94.53 \\
\hline FYM Efficiency (\%) $\mathbf{E}_{\text {org }}$ & 13.01 & 5.43 & 10.10 \\
\hline Nutrient requirement $\left(\mathrm{kg} \mathrm{ha}^{-1}\right)$ & 1.57 & 0.32 & 1.71 \\
\hline
\end{tabular}

Table.7 Fertilizer adjustment equations derived for SRI hybrid rice (var.IRH-103)

\begin{tabular}{|c|c|}
\hline Fertilization & Fertilizer adjustment equations \\
\hline \multirow{3}{*}{ NPK + FYM } & $\mathrm{FN}=3.93 \mathrm{Y}-0.82 \mathrm{SN}-0.33 \mathrm{FYM}$ \\
\cline { 2 - 2 } & $\mathrm{FP}_{2} \mathrm{O}_{5}=1.03 \mathrm{Y}-1.03 \mathrm{SP}-0.18 \mathrm{FYM}$ \\
\hline & $\mathrm{FK}_{2} \mathrm{O}=1.81 \mathrm{Y}-0.17 \mathrm{SK}-0.11 \mathrm{FYM}$ \\
\hline
\end{tabular}

*FN, FP and FK represents the $\mathrm{N}, \mathrm{P}_{2} \mathrm{O}_{5}$ AND $\mathrm{K}_{2} \mathrm{O}\left(\mathrm{kg} \mathrm{ha}^{-1}\right)$ given in fertilizer form. FYM represents Farm Yard Manure $\left(\mathrm{t} \mathrm{ha}^{-1}\right)$. SN, SP and SK represents the NPK values of soil test. Y represents crop yield. ( $\left(\mathrm{ha}^{-1}\right)$

Table.8 "Ready reckoners for fertilizer N P and K recommendations based on soil test levels with 5 tons of FYM for SRI Rice (IRH-103) in Vertisols of Chhattisgarh"

\begin{tabular}{|c|c|c|c|c|c|c|c|c|c|c|c|}
\hline \multirow{2}{*}{\multicolumn{3}{|c|}{$\begin{array}{l}\text { Soil Test Values } \\
\quad\left(\mathrm{kg} \mathrm{ha}^{-1}\right)\end{array}$}} & \multicolumn{9}{|c|}{ Yield Target of Rice (q/ha) } \\
\hline & & & \multicolumn{3}{|c|}{$65\left(q h^{-1}\right)$} & \multicolumn{3}{|c|}{$75\left(q\right.$ ha $\left.^{-1}\right)$} & \multicolumn{3}{|c|}{$85\left(q\right.$ ha $\left.^{-1}\right)$} \\
\hline $\mathbf{S N}$ & S P & SK & FN & FP & FK & FN & FP & FK & $\mathrm{FN}$ & FP & FK \\
\hline 150 & 4 & 200 & 131 & 62 & 83 & 171 & 72 & 101 & 210 & 83 & 119 \\
\hline 175 & 6 & 225 & 111 & 60 & 79 & 150 & 70 & 97 & 190 & 80 & 115 \\
\hline 200 & 8 & 250 & 90 & 58 & 75 & 130 & 68 & 93 & 169 & 78 & 111 \\
\hline 225 & 10 & 275 & 70 & 56 & 70 & 109 & 66 & 88 & 149 & 76 & 107 \\
\hline 250 & 12 & 300 & 49 & 54 & 66 & 89 & 64 & 84 & 128 & 74 & 102 \\
\hline 275 & 14 & 325 & 29 & 52 & 62 & 68 & 62 & 80 & 108 & 72 & 98 \\
\hline 300 & 16 & 350 & 8 & 50 & 58 & 48 & 60 & 76 & 87 & 70 & 94 \\
\hline 325 & 18 & 375 & 8 & 48 & 53 & 27 & 58 & 71 & 67 & 68 & 90 \\
\hline 350 & 20 & 400 & 8 & 45 & 49 & 7 & 56 & 67 & 46 & 66 & 85 \\
\hline 375 & 22 & 425 & 8 & 43 & 45 & 7 & 54 & 63 & 26 & 64 & 81 \\
\hline 400 & 24 & 450 & 8 & 41 & 41 & 7 & 52 & 59 & 5 & 62 & 77 \\
\hline
\end{tabular}




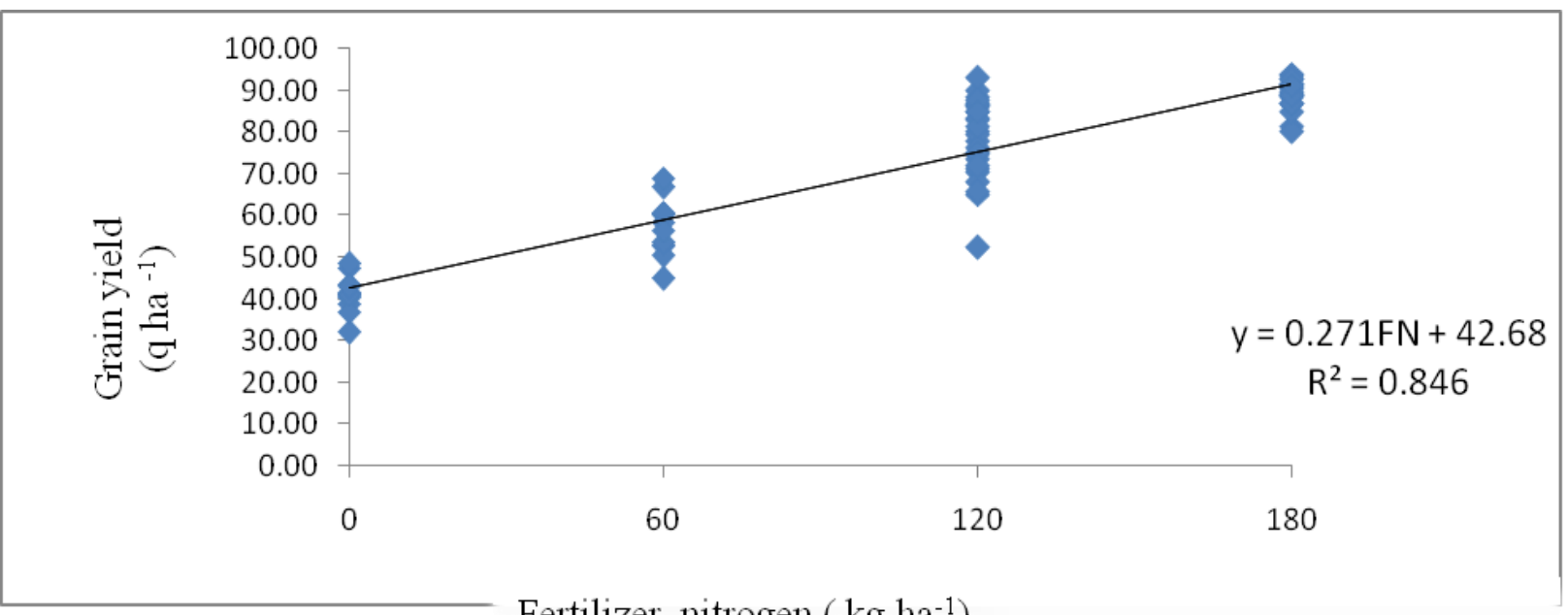

Fertilizer nitrogen $\left(\mathrm{kg} \mathrm{ha}^{-1}\right)$

Fig.1 Response of Rice (grain yield) to added fertilizer nitrogen $\left(\mathrm{kg} \mathrm{ha}^{-1}\right)$

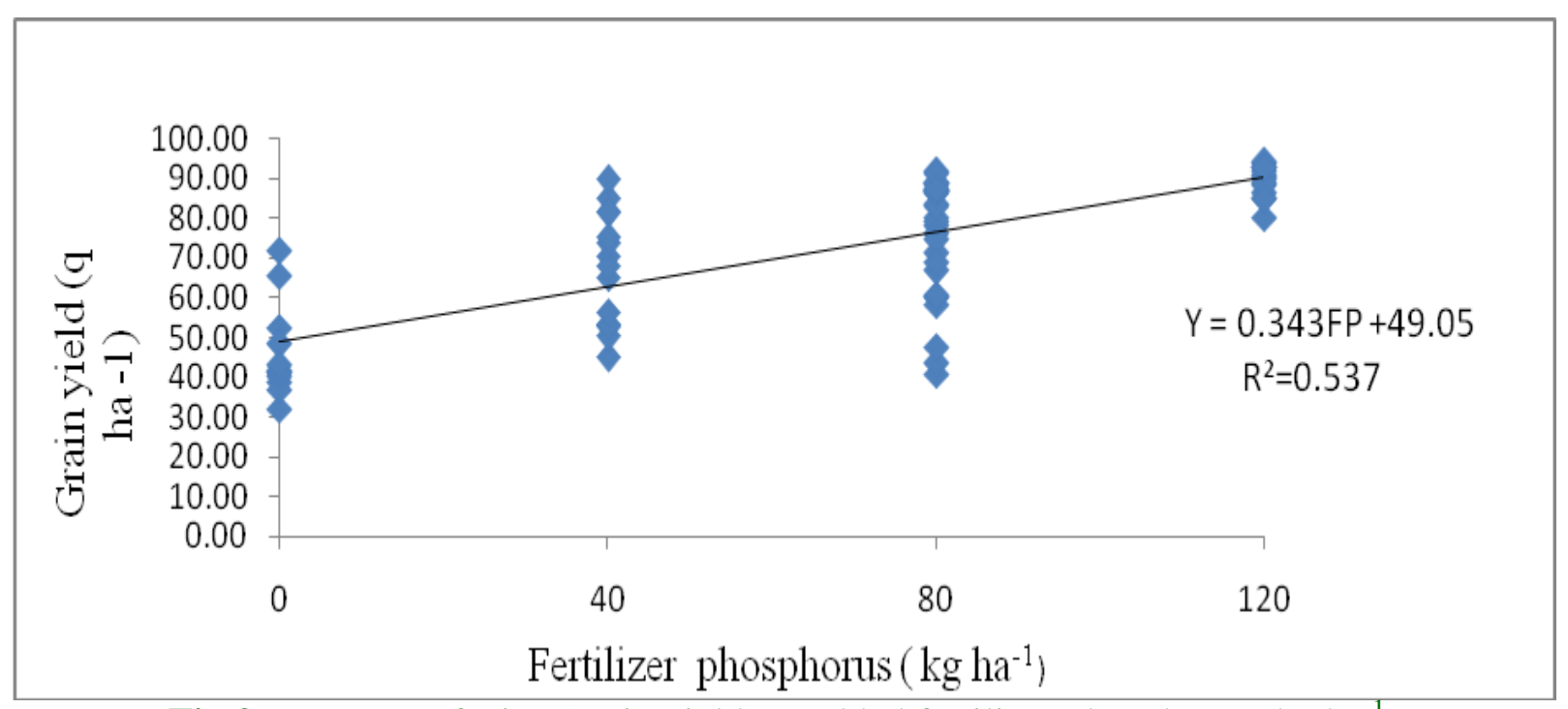

Fig.2 Response of Rice (grain yield) to added fertilizer phosphorus $\left(\mathrm{kg} \mathrm{ha}^{-1}\right)$

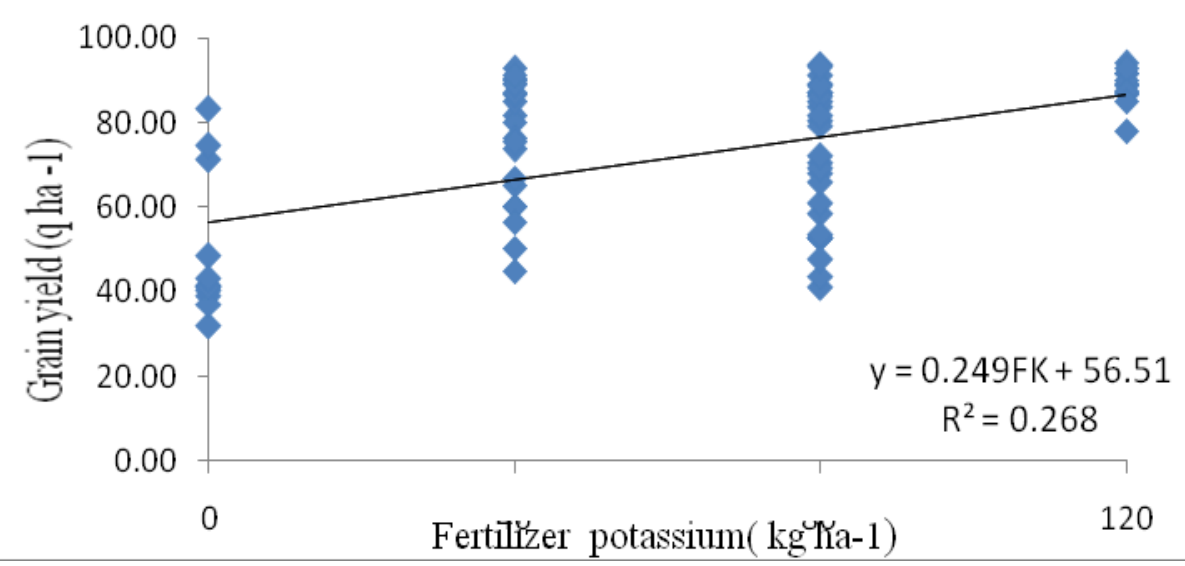

Fig.3 Response of Rice (grain yield) to added fertilizer potassium ( $\left.\mathrm{kg} \mathrm{ha}^{-1}\right)$ 


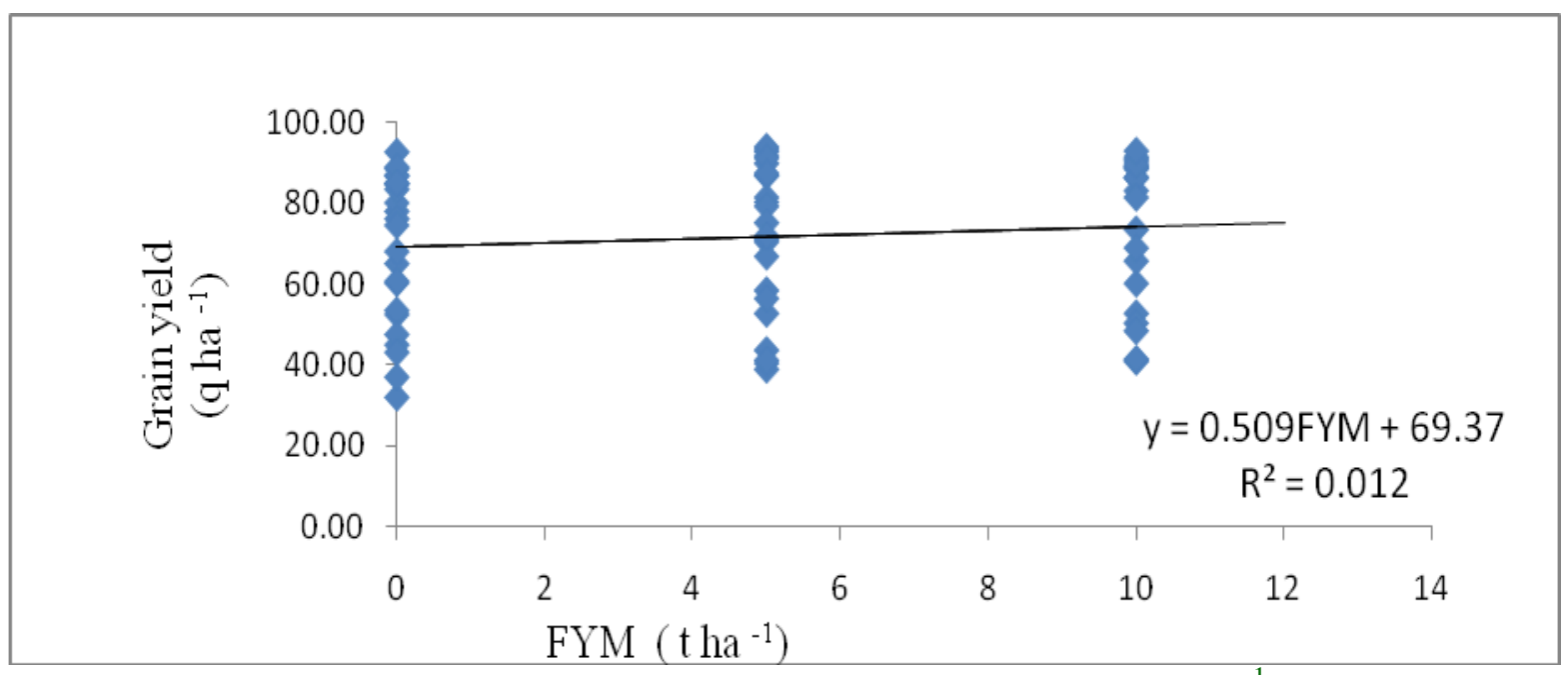

Fig.4 Response of Rice (grain yield) to added FYM (q ha ${ }^{-1}$ )

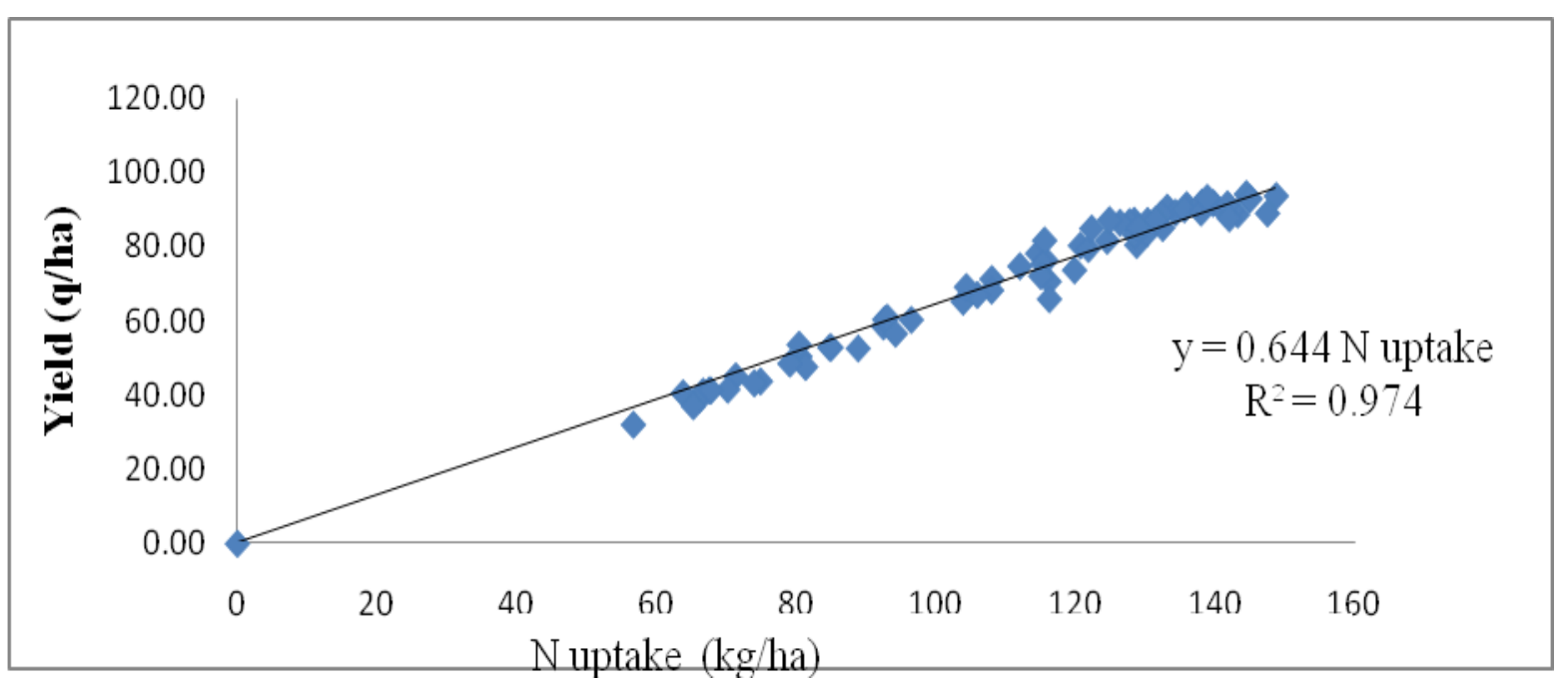

Fig.5 Relationship between Rice grain yield and N nutrient uptake

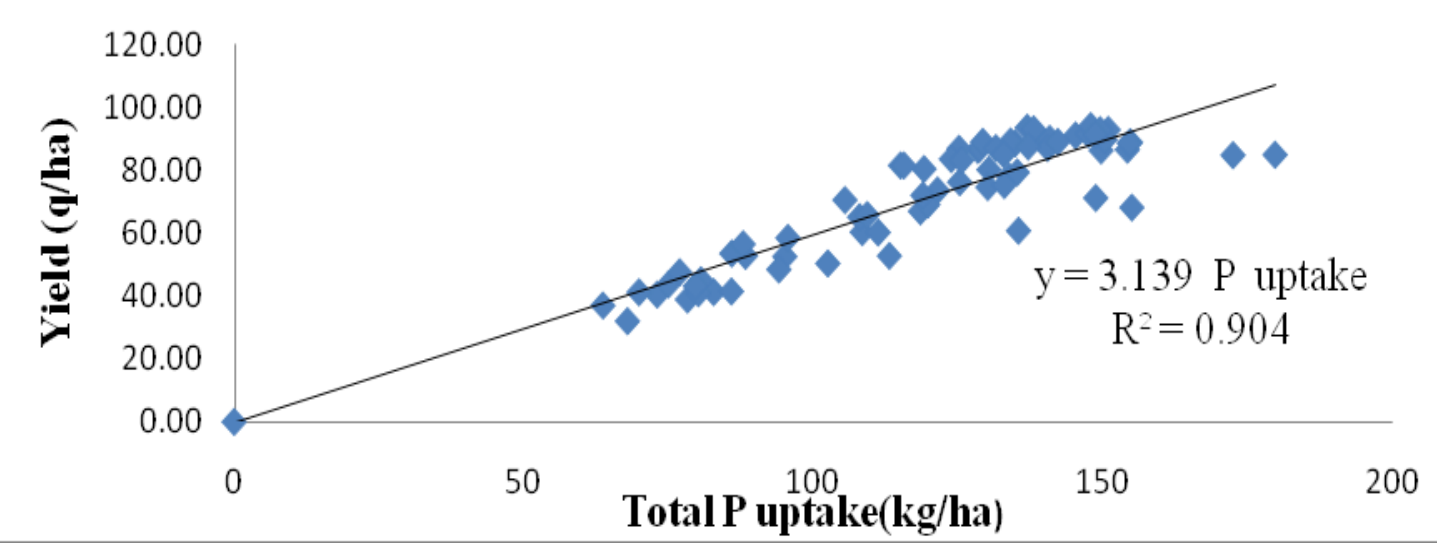

Fig.6 Relationship between Rice grain yield and P nutrient uptake 


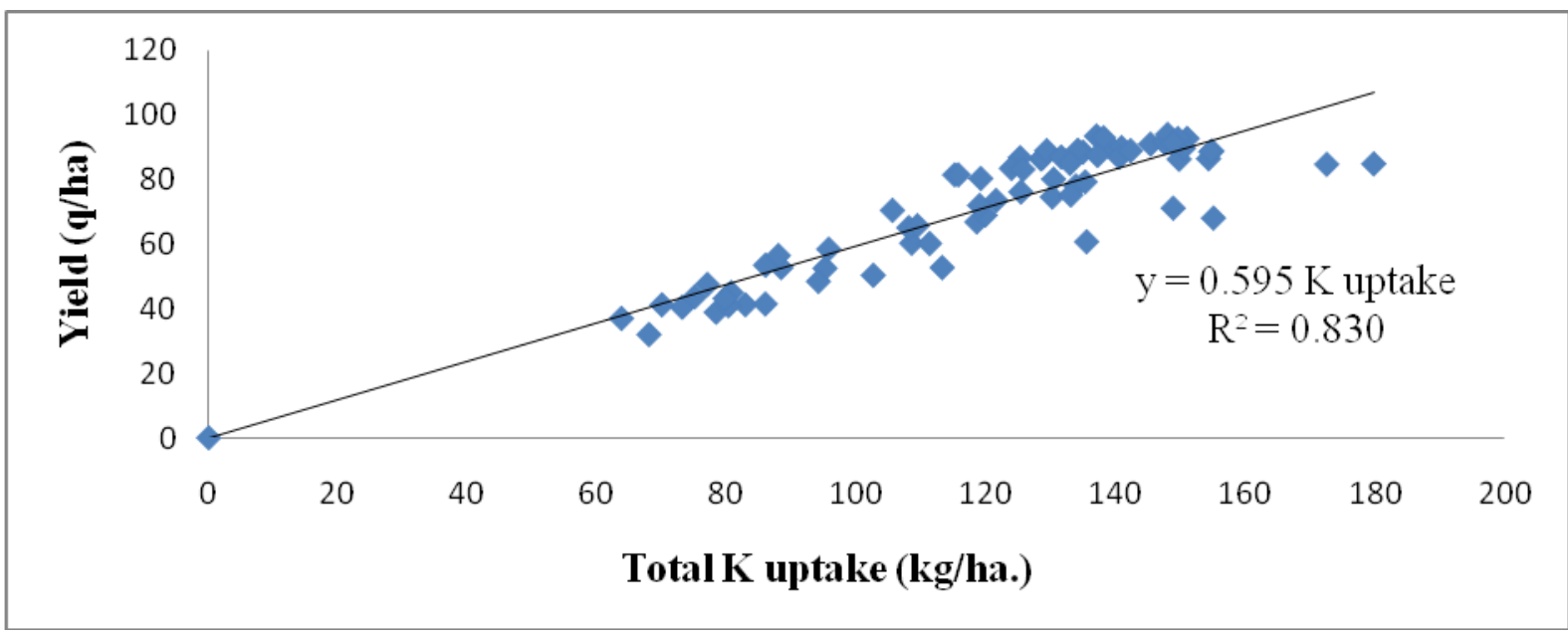

Fig.7 Relationship between Rice grain yield and K nutrient uptake

\section{Estimation of fertilizer adjustment equations for SRI hybrid rice}

The basic parameters such as "nutrient requirement, efficiencies of fertilizers, soil test and organic source (FYM)" were used to evolve fertilizer adjustment equations for SRI hybrid rice crop for achieving a definite yield goal. equations were evolved by using these basic parameters for adjustment of fertilizer $\mathrm{N}, \mathrm{P}_{2} \mathrm{O}_{5}$ and $\mathrm{K}_{2} \mathrm{O}$ in SRI hybrid rice crop (var.IRH-103) are given in table 7.

\section{Ready reckoners chart for fertilizer recommendations (SRI Rice)}

The ready reckoners for rice with the use of 5 tones of FYM are shown in Table 8 . The fertilizer requirement reduced with the use of FYM resulting in the saving of chemical fertilizer although it is a meager amount however, application of chemical fertilizer with FYM in integrated manner has beneficial by several ways in terms of soil fertility and physical properties improvement.

\section{References}

Agricultural statistics table (2017), Department of Revenue, Raipur (Chhattisgarh) http://revenue.cg.nic.in

Banerjee, H. and Pal, S. 2009. Integrated nutrient management for rice-rice cropping system. Oryza, 46 (1) 32-36.

Mahender Kumar, R., Rama Prasad A.S., Singh, S.P., Ramesha, M.S. and Subbaiah, S.V. 2009. Responses of hybrids to $\mathrm{N}, \mathrm{P}$ and $\mathrm{K}$ in different rice soils. Oryza, 46(4): 293-298

Pandey, D., Payasi, D. K., \& Pandey, N. (2014). Effect of organic and inorganic fertilizers on hybrid rice. International Journal of Current Research, 6(5), 6549-6551.

Parihar, M., Singh, Y. V., De, P., \& Jat, L. K. (2015). Validation of soil test based fertilizer prescription model under integrated plant nutrient management system for maize in an Inceptisol of Varanasi, India. Journal of Pure and Applied Microbiology, 9(4), 3045-3050.

Piper, C.S. 1966. Soil and Plant Analysis. Hans Publisher, Bombay. pp. 85-102.

Pocket Book of Agricultural Statistics (2017). Government of India Ministry of Agriculture \& Farmers Welfare Department of Agriculture, Cooperation \& Farmers Welfare Directorate of Economics \& Statistics New Delhi. Pp27, 32) 
Ramamoorthy, B., Narasimhan, R. L. and Dinesh, R.S. (1967). "Fertilizer application for specific yield targets of Sonara-64". Indian Farming, 17 (5): 43 45

Regar, K. L., \& Singh, Y. V. (2014). Fertilizer recommendation based on soil testing for the targeted yield of rice in eastern plain zone of Utter Pradesh. The Bioscan, 9(2), 531-534.

Sahu V., Srivastava L.K., Mishra V.N.,Banwasi R. And Jatav G.K.(2017),Development of fertilizer prescription equation for SRI rice-wheat cropping system under integrated plant nutrient system in Vertisols of Chhattisgarh plains. Annals of Plant and Soil Research 19(4): 413-417 (2017)

Santhi, R., A. Bhaskaran, S. Poongothai, S. Maragatham, R. Natesan, K.M.Sellamuthu, V.P. Duraisami, V. Velu, K. Appavu, and P. Murugesa Boopathi. 2010. Decision Support System for Integrated Fertiliser prescriptions, Computer software, Dept.of Soil Science \& Agrl.Chemistry,
TNAU, Coimbatore. 21 (1): 78-81

Singh, K.N., Biswas S.K. 2000. Effect of integrated nutrient management on Typic Haplaquent on yield and nutrient availability in a rice wheat cropping system. Australian Journal of Agricultural Research, 52(8): 855-858

Singh, S.P., Sreedevi, B. and Kumar, R.M. 2009. Integrated nitrogen management for seed production of hybrid rice. Oryza, 46 (3): 254-256

Srivastava L.K. , Mishra V.N. and Jatav G.K.(2017)Rice Response to Fertilizer Nutrients as Influenced by Integrated Nutrients Management in Vertisols of Chhattisgarh Plain, India. Int.J.Curr.Microbiol.App.Sci (2017) 6(2): 1709-1719.

Truog, E. (1960). "Transaction, Seventh International Congress Soil Science", 4 (7): 46-52.

Vadlamani, Raja.,"Hybrid Rice In India"(2016)- Status https://www.linkedin.com/pulse/hybridrice-india-2016-status-raja-vadlamani.

\section{How to cite this article:}

Anurag Gupta, Rakesh Banwari, L. K. Srivastava and Jatav. G. K. 2020. Calibration of Soil Test, Fertilizer Dose and Crop Yield with and without FYM for Hybrid Rice (Var.Irh-103) under Sri In Vertisol of Chhattisgarh Plain. Int.J.Curr.Microbiol.App.Sci. 9(03): 3113-3123. doi: https://doi.org/10.20546/ijcmas.2020.903.356 